\title{
Antagonism of Bacillus subtilis Against Sclerotinia sclerotiorum on Lactuca sativa
}

\author{
Fernando P. Monteiro ${ }^{1}$, Larissa C. Ferreira ${ }^{1}$, Leandro P. Pacheco ${ }^{2} \&$ Paulo E. Souza ${ }^{1}$ \\ ${ }^{1}$ Department of Plant Pathology, Federal University of Lavras, Lavras, Brazil \\ ${ }^{2}$ Department of Plant Science, Federal University of Piauí, Bom Jesus, Brazil \\ Correspondence: Fernando P. Monteiro, Department of Plant Pathology, Federal University of Lavras, Lavras, \\ Brazil. Tel: 55-35-9169-5159. E-mail: fernandopereiram@bol.com.br
}

\author{
Received: January 10, 2013 Accepted: February 20, 2013 Online Published: March 15, 2013 \\ doi:10.5539/jas.v5n4p214 URL: http://dx.doi.org/10.5539/jas.v5n4p214
}

\begin{abstract}
The objectives of this study were select and test the efficiency of the Bacillus subtilis strain and its metabolites against Sclerotinia sclerotiorum in all stages of its cycle. The bacterium was selected by performing antibiosis test against this and other pathogens, being selected that one who obtained the best result. For the assessment of radial mycelial growth under the influence of metabolite, this was added to PDA culture medium and the fungus was placed on its surface, being evaluated daily in the both directions. The test with volatiles was performed by using the two surfaces of the Petri dish, each containing culture medium, putting the fungus and the bacteria separately one on each surface without any contact between them, being measured every day the mycelial growth dimensions. For the evaluating the direct effect on the sclerotia was applied $1 \mathrm{~mL}$ of bacterial suspension (1.002 absorbance value at wavelength of $550 \mathrm{~nm}$ ) to observe the possible presence of harmful substances to this structure. The test for the possible protection provided by the strain on lettuce (Lactuca sativa) was performed with four varieties grown up to 60 days after sowing, when was sprayed the bacterial suspension following the best incubation time tested. The antibiosis test showed a decreased by $16.33 \%$ compared to control. The metabolite, when mixed into the culture medium showed better inhibition results of the radial mycelial growth when concentration and incubation time were greater. The volatile test showed a reduction of $83.33 \%$ on mycelial growth. For the test with sclerotia, the mycelial and carpogenic germination were higher than the control. In vivo treatments with lettuces were observed differentiated levels of control, and some plants showed extremely sensitive to bacterial cells concentration used. This study show the $B$. subtilis as a biocontrol agent applying different strategies to control the pathogen and also the hipensensitive plant reaction in some cases.
\end{abstract}

Keywords: metabolites, lettuce, sclerotia, apothecia and phytopathology

\section{Introduction}

Sclerotinia sclerotiorum (Lib.) de Bary is a phytopathogenic fungus and under appropriate conditions can cause a disease called white mold. Its importance as a pathogen is praised for being a necrotrophic fungus and produce in the course of its life cycle, a weather resistant structure, known as sclerotia. The efficient control of this pathogen is still a challenge, and treatment is carried out mainly using biological control agents, fungi and bacteria, as well as targeted fungicides application when it inhabits lower plant parts.

The fungus is the etiological agent of white mold disease in several crops commercially exploited, it is important for the damage caused and destructive potential, when no control measures are employed. Losses of up to $15 \%$ due to Sclerotinia species commonly happen and losses of up to $60 \%$ have been reported in specific conditions (Subbarao, 1998). The control and eradication of this pathogen is difficult due to the existence of a resistance structure called sclerotia that can survive in soil for years without hosts or favorable condition for development (Coley-Smith \& Cooke, 1971). Authors such as Huang et al. (2000), and Mueller et al. (1999), pointed out that even using different methods of control were remaining sufficient sclerotia to cause the disease. In attempting to control the pathogen, metabolites from Bacillus spp. has been used in different ways against the fungus and distinct results were obtained depending of the hosts (Fernando et al., 2007; Yang et al., 2009).

The metabolites synthesized by bacteria, fungi and actinomycetes are able to prevent the growth of other microorganisms. According Kennedy (1999), the substances that compose metabolites are present in 
micro-organisms differ in specific structure and distribution. Some bacteria when placed in culture medium with conducive conditions to development, produces phytotoxic metabolites such as lactic and acetic acids, cyanide and antibiotics (Bakker \& Schippers, 1987; Kloepper et al., 1989). The metabolite produced depends of the environment components in which they are, as well as the environmental conditions in which they are inserted (Konings et al., 1992).

Therefore we can say that all secondary metabolites produced depend primarily of the medium in which they are inserted, and subsequently require the presence of specifics enzyme complex (Kliebenstein, 2004). Secondary metabolites are products derived from primary metabolites and although not necessarily essential to the organism, perhaps can generate some advantages to ensure their survival (Santos, 1999). According Kutchan (2001), secondary metabolites have its synthesis influenced by environmental conditions. This influence of environmental condition are also affirmed by McCall and Karban (2006), who point out that the metabolites synthesized and accumulated in plants is directly related to environmental factors. All these specifics may change the result obtained in disease control. According Hammami et al. (2009) the effect in situ by exposure live $B$. subtilis cells may incite the growth promoting and/or biocontrol. In nature this biocontrol can be promoted directly or indirectly by producing compounds antagonistic or induce resistance in plants after application (Ryu et al., 2004; Ongena et al., 2007).

Bacillus subtilis is an example of antagonistic bacteria that usually act through antibiosis and eventually by parasitism and competition for space and nutrients (Nagórska et al., 2007). Microorganisms acting on antibiosis, generally have a wide action spectrum, and for this reason the fungal inhibition by producing toxic substances is more efficient than any other mechanism of action involved (Kupper et al., 2003; Leelasuphakul et al., 2008). Santos et al. (2006) reported that Bacillus sp. is the most numerous rhizobacteria in the soil. This high presence on the ground reveals the great competitive potential, when it is located on the environment with several other microorganisms. According Kupper et al. (2003), some Bacillus sp. lineages produce thermostable metabolites, capable of maintaining their activities even after autoclaving, which facilitates large scale production. Marroni and Germani (2011) working with non-volatile metabolites of Bacillus sp. inhibited the development of Macrophomina phaseolina, a fungus that produce sclerotia, as resistant structure. In the specific case of $S$. sclerotiorum, Hou et al. (2006) reported that among 1,140 isolates of Bacillus sp., 8.2\% showed antifungal activity to this pathogen.

Leelasuphakul et al. (2008) found strains of Bacillus sp. inhibiting the mycelial growth of Penicillium digitatum. In the same way Santos et al. (2006) related strains of Bacillus sp. B. subtilis, Bacillus megaterium pv. cerealis and Bacillus pumilus controlling the bacterial fruit blotch, known as Acidovorax avenae subsp. citrulli, on melon seedlings due to lipopeptides compounds present of the metabolites produced. Based on these studies the use of Bacillus sp. as biological control agents has numerous applications.

Kai et al. (2007) demonstrated that B. subtilis is capable of producing volatile elements with antifungal activity. However, many of the volatile substances produced by this microorganism are unknown yet. Chen et al. (2008) identified by gas chromatography mass spectrometry (GC-MS) 14 volatile compounds of $B$. subtilis. The quality of some antifungal compounds such as 2-ethylhexanol, 2,4-bis (2-methylpropyl) phenol, 4-hydroxybenzaldehyde and 2-nonanone was also demonstrated in other pathosystems (Wang et al., 2004, Almenar et al., 2007). Non-volatile metabolites from $B$. subtilis, besides possessing antifungal metabolites are also effective in controlling some phytobacterias (Cunha et al., 2006).

In analyzing the attempts for management of S. sclerotiorum, chemical treatment is not recommended as uniquely way to control this pathogen due to its low efficiency (Paula Júnior et al., 2004), so the use of alternative and sustainable practices for the management, has been widely used, and the biological control using metabolites from bacteria assumes importance in combating this pathogenic organism. The objective of this work is to know the fungicidal and/or fungistatic effect of metabolites produced by $B$. subtilis in various phases of the $S$. sclerotiorum life cycle.

\section{Materials and Methods}

\subsection{Antibiosis Test}

First of all, one experiment was performed in order to isolate the bacteria that colonize the sclerotia. For this test, 20 sclerotia were placed on the surface of plastic plates containing a mixture of soil and sand in the same ratio, which were kept in an incubator at $20^{\circ} \mathrm{C}$ for 60 days. After isolating the bacteria, an essay was performed to attest the fungistatic or fungicidal activity of metabolites produced. We used Petri dishes containing PDA culture medium to make the experiment. In testing, disks measuring $9 \mathrm{~mm}$ in diameter containing the fungus were inserted on the medium in one pole of the plate. On the opposite pole was inserted $100 \mu \mathrm{L}$ of bacterial 
suspension with absorbance value of $1.002 \mathrm{~nm}$ at $550 \mathrm{~nm}$ wavelength. After the growth of both organisms were measured the inhibition zones.

\subsection{Volatile Test}

The presence of volatile substances was observed using both surfaces of the Petri dish, fixing one another with the aid of plastic film. Thus was inserted PDA culture medium inside to two larger parts of the Petri dishes. Caring for there was no contact between the microorganisms, has been inserted a disc with the mycelium in the center of the one those surfaces. In another surface, parallel grooves were made, derived from a bacterial suspension containing 1.002 of absorbance at a wavelength of $550 \mathrm{~nm}$. The plate containing the mycelium and that plate containing the bacteria was fixed one to another. The radial growth measurements were measure daily until take up the entire plate. The treatment was compared with a control without bacteria, generating data to calculate the inhibition percentage.

\subsection{Metabolites Production}

For this process, a bacterial suspension was prepared with saline solution $0.85 \%(\mathrm{w} / \mathrm{v})$, which was calibrated according absorbance readings given by a spectrophotometer $(\mathrm{A}=1.002$ at $\lambda=550)$. We transferred $1 \mathrm{~mL}$ of the suspension to five flasks containing $75 \mathrm{~mL}$ of culture medium MB1 liquid (Kado \& Heskett, 1970). The bottles were covered with aluminum foils and placed on a shaker table at $120 \mathrm{rpm}$ for 24, 48, 72,96 and 120 hours. After this time, we put all flasks into the autoclave for sterilization process at 40 minutes in $120^{\circ} \mathrm{C}$.

\subsection{Mycelial Growth Test}

Once the solution containing the metabolites produced in different incubation times, they were diluted into the PDA medium being adjusted at six different concentrations, $0 \%$ (control), $1 \%, 5 \%, 10 \%, 15 \%$ and $20 \%$. Then, it was poured in Petri dishes with $9 \mathrm{~cm}$ in diameter. Mycelium discs of $S$. Sclerotiorum with $9 \mathrm{~mm}$ in diameter were transferred to the center of the plates containing PDA medium and metabolites. The set was sealed with plastic wrap and set aside in cold chamber at $20^{\circ} \mathrm{C}$ and 12 hours photoperiod. Mycelial growth was assessed with 24 hours apart, marking the two diameters perpendicular to the disk mycelium. The experiment was conducted in three replicates for each concentration.

\subsection{Survival of Sclerotia in Soil Test}

Into the plastic boxes was placed a mixture of sand and soil (1:1), previously sterilized in autoclave at $120^{\circ} \mathrm{C}$ for 1 hour. The sclerotia used were previously selected and disinfected. For disinfection, they were immersed for 30 seconds in ethanol $70 \%$, one minute in sodium hypochlorite $2 \%$ and three times in distilled water to remove the excess. The arrangement of sclerotia in the substrate occurred uniformly arranged in a standard $5 \times 5$, resulting in total of 25 sclerotia per box. Then, was pipetted $500 \mu \mathrm{L}$ of bacterial suspension on each sclerotia, proceeding the same for all five incubation times tested (24, 48, 72, 96 and 120 hours). For the control was applied $500 \mu \mathrm{L}$ of sterile water on each sclerotia. The set was sealed with plastic film and set aside in a growth chamber at $20^{\circ} \mathrm{C}$ and 12 hours photoperiod.

\subsection{Ascospores Germination Test}

Performing this step the metabolite was prepared similar to item 2.3 until 120 hours of incubation. It was tested in four concentrations of bacterial suspension $(5 \%, 10 \%, 15 \%$ and $20 \%)$ and a control containing sterile distilled water $(0 \%)$. Ascospores from apothecia were obtained after incubation of 20 sclerotia for 40 days in the cold chamber at $20^{\circ} \mathrm{C}$ and 12 hours of light. The bacterial cells were placed in contact with the ascospores for a period of 48 hours, sufficient time for spore germination. The significant results obtained in the F test were used to make a regression analysis.

\subsection{In Vivo Test}

For the in vivo test we used four varieties of lettuce named Pescada, Camurim, Parma and Badejo, being cultivated for 30 days into the growth chamber. Inside the pots was added six sclerotia previously disinfected arranged on the base of the lettuce plants. In this experiment was only tested the incubation period that showed the best results in the previous tests, which is the incubation for 120 hours and the suspension was applied to the point of runoff. After applying all the treatments, the plants were incubated in a growth chamber at $20^{\circ} \mathrm{C}$ and 12 hours of light. The plants were evaluated for weight and number of healthy leaves.

\subsection{Statistical Analysis}

Where it was applicable data were subjected to analysis of variance with statistical program SISVAR 4.0 (Ferreira et al., 2000). When it was significant by $\mathrm{F}$ test, means were compared by the Tukey test at $5 \%$ probability. 


\section{Results and Discussion}

\subsection{Antibiosis Test}

The metabolite presented antagonism to fungus with a reduction of $17.7 \%$ in mycelial growth (Table 1). Even after two weeks of the first measuring, these values have not changed in subsequent evaluations, suggesting the high efficiency of these substances in the control of S. sclerotiorum. Zhang et al. (2008) working with B. subtilis also achieved zones of inhibition between 10 and $20 \mathrm{~mm}$ against $S$. sclerotiorum.

Table 1. Halo inhibition in antibiosis test

\begin{tabular}{lll}
\hline Treatment & Mycelial growth $(\mathbf{C m})$ & Halo inhibition $(\mathbf{C m})$ \\
\hline B. subtilis & $7.53 \mathrm{~b}$ & 1.46 \\
Control & $9 \mathrm{a}$ & - \\
\hline
\end{tabular}

$* \mathrm{p}$ value -0 ; Coefficient of variation $(\mathrm{CV})-0,22$.

Favourable results were also found by Yilmaz (2006) who demonstrated the efficiency of Bacillus sp. against Pseudomonas fluorescens and Micrococcus flavus. Han et al. (2005) when working with Bacillus sp. also observed inhibition zones against Streptomyces scabies, Pseudomonas syringae pv. syringae, Fusarium oxysporum and Alternaria mali. This step was used in the initial tests in a practical way to know if the bacterial isolate produces harmful substances to the development of pathogens.

\subsection{Volatile Test}

The plates containing the bacteria grew less than the control with a reduction of $83.84 \%$ on mycelial growth, which attests that our $B$. subtilis has fungistatic volatile substances (Table 2).

Table 2. Mycelial growth index (MGI) and mycelial growth $(\mathrm{cm})$

\begin{tabular}{lll}
\hline Treatment & MGI (cm/day) & Mycelial growth (cm) \\
\hline B. subtilis & $0.24 \mathrm{~b}$ & $1.5 \mathrm{~b}$ \\
Control & $1.5 \mathrm{a}$ & $9 \mathrm{a}$ \\
\hline
\end{tabular}

* p-value for MGI and Mycelial growth, respectively: 0, CV 2.04; 0, CV 3.56.

Table 3. Colonization of the resistance structures and their effects on germination

\begin{tabular}{|c|c|c|c|c|}
\hline Incubation time & Colonized sclerotia & Mycelial germination & Carpogenic germination & Surface appearance \\
\hline 24 hours & 6.67 & 1.00 & 0.00 & $\begin{array}{l}\text { Discolored } \\
\text { - no layer }\end{array}$ \\
\hline 48 hours & 7.33 & 1.67 & 0.00 & $\begin{array}{l}\text { Discolored } \\
\text { - no layer }\end{array}$ \\
\hline 72 hours & 16.67 & 1.00 & 0.00 & $\begin{array}{l}\text { Discolored } \\
\text { - no layer }\end{array}$ \\
\hline 96 hours & 15.00 & 1.00 & 0.00 & $\begin{array}{l}\text { Discolored } \\
\text { - no layer }\end{array}$ \\
\hline 120 hours & 20.67 & 0.00 & 0.00 & $\begin{array}{l}\text { Discolored } \\
\text { - no layer }\end{array}$ \\
\hline Control & 0.00 & 13.67 & 2.67 & Black \\
\hline
\end{tabular}

According to Wheatley (2002) volatile organic compounds are molecules which generally have low molecular weight and high vapor pressure. Because of their volatility, these compounds may be scattered over long distances and being a gas can take various forms according to environment. Chaurasia et al. (2005) reported that the production of volatile compounds by $B$. subtilis caused structural deformation in Cladosporium oxysporum and Alternaria alternata. In our study was not observed any hyphae alteration after the contact with volatile. 
The influence of volatile metabolites on mycelial growth was also evaluated by Leelasuphakul (2008) who showed a reduction in the growth of Penicillium digitatum. Chen et al. (2008) noted the antagonistic effect of volatiles generated by $B$. subtilis on mycelial growth of Botrytis cinerea, a sclerotia producer. The use of volatile substances can be used more efficient, especially, in growing areas protected or small properties, but still in a lettuce commercial-scale production. Fialho et al. (2011) obtained $76.59 \%$ of reduction in the S. sclerotiorum mycelial growth when working with volatile organic compounds, which supports our result.
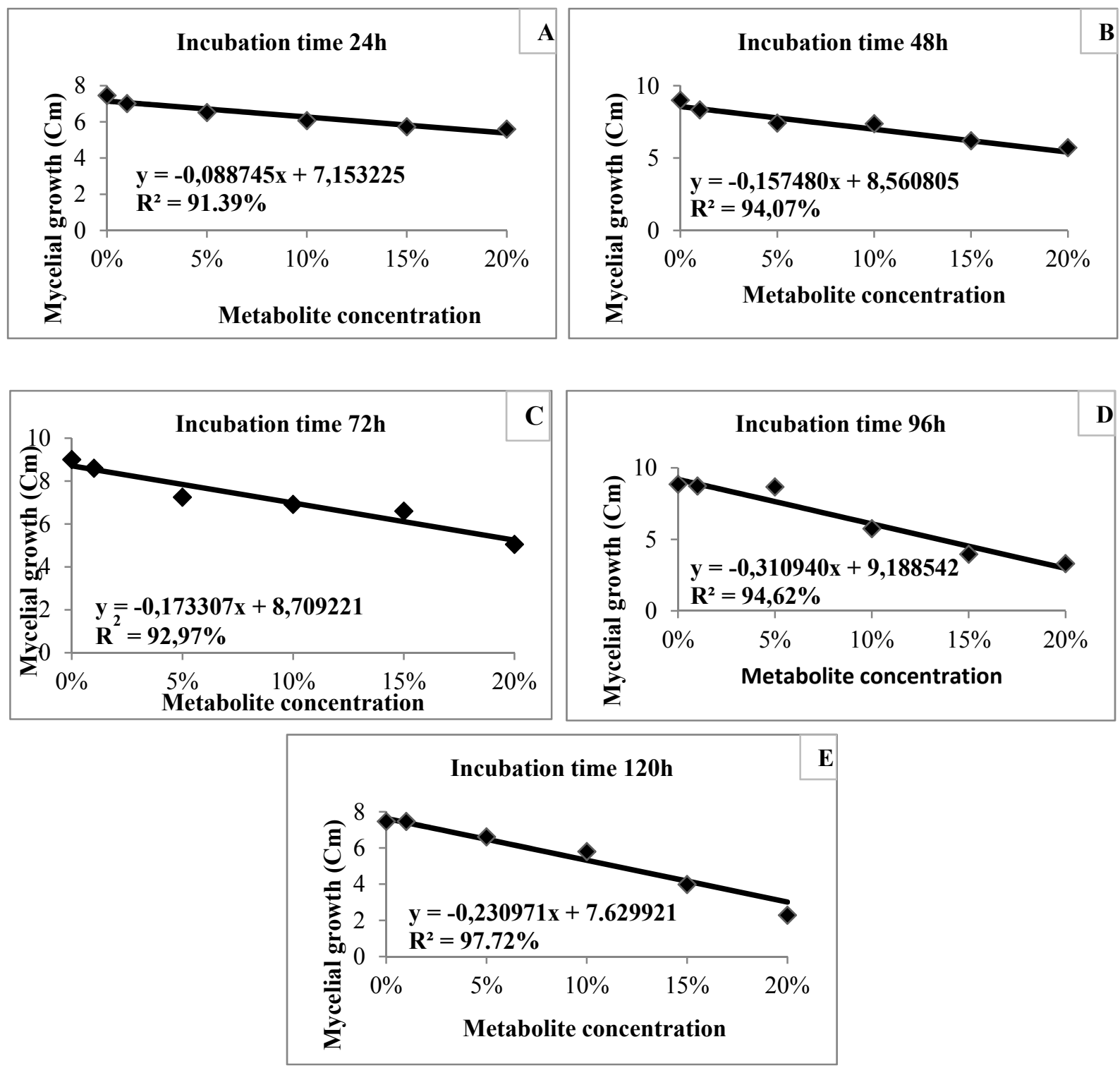

Figure 1. Mycelial growth according to the incubation time and metabolite concentrations. * Significant differences in the F-test at $5 \%$ probability. $24 \mathrm{~h}$ (p-value 0.003, CV 7.62), $48 \mathrm{~h}$ (p-value 0.001, CV 7.99), $72 \mathrm{~h}$

(p-value 0.001, CV 3.77), 96 h (p-value 0.000, CV 4.74) e 120 h (p-value $0.000, \mathrm{CV} 10.19$ )

\subsection{Survival of Sclerotia in Soil Test}

When applying the bacteria on the sclerotia was observed that the incubation time of 120 hours yielded a greater number of sclerotia colonized by bacteria cells, and also prevented the mycelial and carpogenic germination. It was also observed that the sclerotia treated by bacterial cells had changes in color and less resistant with the consistency impaired. 
Remuska and Pria (2007) reported that Bacillus thuringiensis, besides controlling the S. sclerotiorum mycelial growth in $37.44 \%$, additionally did not allow the fungus to form sclerotia. However, this effect is not permanent, since the sclerotia output is delayed by only fungistatic substances. Thus, the search for molecules that decrease the strength and viability of these structures are important for management. Abdullah et al. (2008) worked with culture filtrates of Bacillus amylolquefaciens cultured for 7 days had an average a reduction of $48.67 \%$ in the sclerotia production. Our B. subtilis are able to damage the black layer of sclerotia, which protect the mycelium against adverse environmental factors.

\subsection{Mycelial Growth Test}

Due to the variation in metabolite concentrations and their incubation periods, the best fungistatic results against $S$. sclerotiorum were noted for the treatments which had more concentrated and longer incubation period, reaching up to $69.43 \%$ of control (bacterial cells cultivated for 120 hours and metabolites concentration at $20 \%$ ). However, all treatments had effective inhibition on the mycelial growth of this pathogen (Figure 1).

Zhang and Xue (2010) by cultivating B. subtilis for 10 days achieved a reduction in mycelial growth in $75.1 \%$, when treated with a suspension of bacterial cells and approximately $70 \%$ of control using the cell-free filtrate, which attesting the great potential on biological control to $S$. sclerotiorum.

\subsection{Ascospores Germination Test}

It was observed that the filtrate from cells of $B$. subtilis inhibits twinning of ascospore depending on the concentration used (Figure 2). Testing the concentration of $20 \%$ was observed a decrease of $39.74 \%$ on the spores germination. Yuen et al. (1991) also report the control of S. sclerotiorum ascospores germination using a strain of Bacillus polymyxa inhibiting approximately $40 \%$ of the germination and the growth of germ tubes.

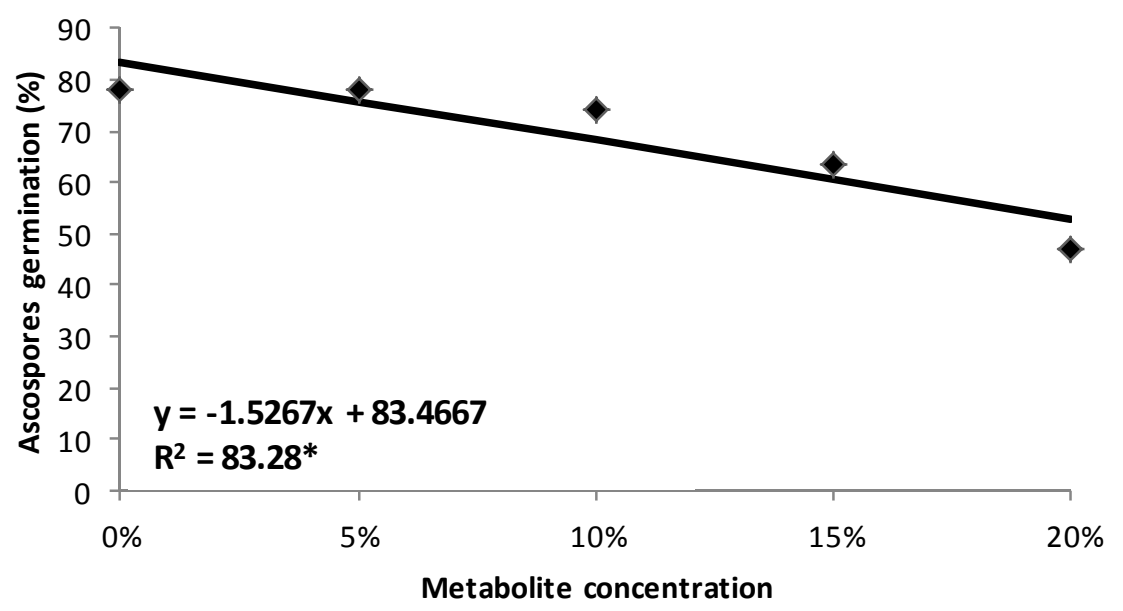

Figure 2. Ascospores germination on the effect of bacterial cells suspension. * Significant differences in the F-test at $5 \%$ probability. $\mathrm{p}$ - values: $0 ; \mathrm{CV}-4.53$

\subsection{In Vivo Test}

When analyzing the performance of the bacterial suspension of B.subtilis, differences can be observed between the lettuce varieties used (Figure 3). Low values for the number of healthy leaves and weight of shoots of cultivar Pescada can be explained by the hypersensitivity reaction of bacterial suspension considering the concentration used. One day after application of the suspension, the plants were already dead. Even plants that did not die have showed fewer healthy leaves and increased colonization by S. sclerotiorum, perhaps by the weakening of the plant tissues once in contact with the bacterial cells. Testing with Badejo cultivar was observed that treatment with B. subtilis was efficient in preventing the disease.

This hypersensitivity in lettuce has been observed by others using suspension of Bacillus sp. However, others have reported positive effects in treatment with Bacillus cells. As Sossai et al. (2011) obtained an increase of $33.33 \%$ on the weight of the shoot, when plants were treated with B. subtilis. According to Araujo et al. (2005) the promoting growth, occurs through the production of hormones or antibiotics, which promote higher growth and plant vigor that were treated. In our work was not observed the growth promotion of lettuces varieties. 


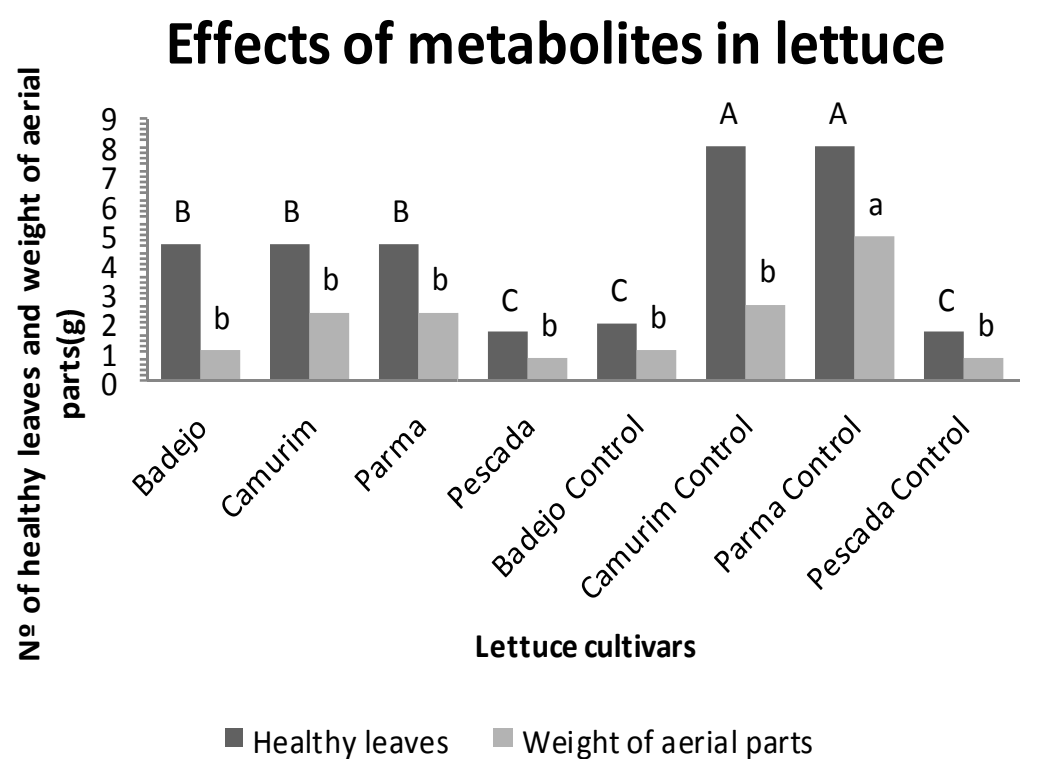

Figure 3. Control of S. sclerotiorum by pulverization the bacterial cells in four lettuce cultivars. Different letters in each category represent significant differences at $5 \%$ probability. p-value for healthy leaves and weight of aerial parts, respectively: $0.0054, \mathrm{CV}: 38.83 ; 0.0020, \mathrm{CV}: 51.53$

The bacterium was also revealed by scanning electron microscopy (Figure 2) to prove the isolation of a single bacterium.

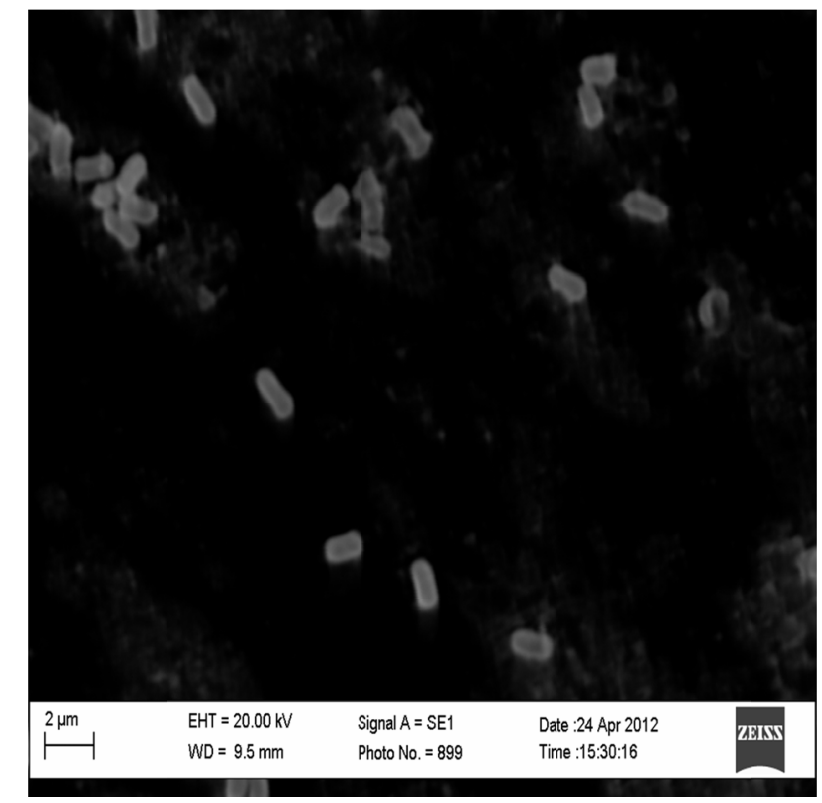

Figure 4. Bacteria antagonist revealed by scanning electron microscopy

\section{Conclusion}

B. subtilis has an antagonistic effect on all stages of the cycle S. sclerotiorum. The use of B. subtilis as biocontrol agent is conditioned on lettuce variety and concentration of bacterial cells used in the suspension.

\section{Acknowlegdement}


To Coordenação de Aperfeiçoamento de Pessoal de Nível Superior (CAPES) and Fundação de Amparo à Pesquisa do Estado de Minas Gerais (FAPEMIG), for the scholarship.

\section{References}

Abdullah, M. T., Ali, N. Y., \& Suleman, P. (2008). Biological control of Sclerotinia sclerotiorum (Lib.) de Bary with Trichoderma harzianum and Bacillus amyloliquefaciens. Crop protection, 27(10), 1354-1359. http://dx.doi.org/10.1016/j.cropro.2008.05.007

Almenar, E., Valle, V. D., Catalla, R., \& Gavara, R. (2007). Active package for wild strawberry fruit (Fragaria vesca L.). Journal of Agricultural and Food Chemistry, 55, 2240-2245. http://dx.doi.org/10.1021/jf062809m

Araujo, F. F., Henning, A. A., \& Hungria, M. (2005). Phytohormones and antibiotics produced by Bacillus subtilis and their effects on seed pathogenic fungi and on soybean root development. World Journal of Microbiology and Biotechnology, 21, 1639-1645. http://dx.doi.org/10.1007/s11274-005-3621-x

Bakker, A. W., \& Schippers, B. (1987). Microbial cyanide production in the rhizosphere in relation to potato yield reduction and Pseudomonas spp. mediated plant growth stimulation. Soil Biology and Biochemistry, 19(4), 451-457. http://dx.doi.org/10.1016/0038-0717(87)90037-X

Chaurasia, B., Pandey, A., Palni, L. M. S., Trivedi, P., Kumar, B., \& Colvin, N. (2005). Diffusible and volatile compounds produced by na antagonistic Bacillus subtilis strain cause structural deformations in pathogenic fungi in vitro. Microbiological Research, 160, 75-81. http://dx.doi.org/10.1016/j.micres.2004.09.013

Chen, H., Xiao, X., Wang, J., Wu, L., Zheng, Z., \& Yu, Z. (2008). Antagonistic effects of volatiles generated by Bacillus subtilis on spore germination and hyphal growth of the plant pathogen, Botrytis cinerea. Biotechnology letter, 30, 919-923. http://dx.doi.org/10.1007/s10529-007-9626-9

Coley-Smith, J. R., \& Cooke, R. C. (1971). Survival and germination of fungal sclerotia. Annual Review of Phytopathology, 9, 65-92. http://dx.doi.org/10.1146/annurev.py.09.090171.000433

Cunha, J. de F., Picoli, E. A. de T., Alfenas, A. C. E., \& Gonçalves, R. C. (2006). Efeito (in vitro) de antibióticos e rizobactérias no controle de bactérias fitopatogênicas ao Eucalyptus spp. Revista Árvore, 30(6), 871-876. http://dx.doi.org/10.1590/S0100-67622006000600001

Fernando, W. G. D., Nakkeeran, S., Zhang, Y., \& Savchuk, S. (2007). Biological controlo of Sclerotinia sclerotiorum (Lib.) de Bary by Pseudomonas and Bacillus species on canola petals. Crop Protection, 26(2), 100-107. http://dx.doi.org/10.1016/j.cropro.2006.04.007

Ferreira, D. F. (2000). Análises estatísticas por meio do Sisvar para windows versão 4.0. Reunião anual da região brasileira da sociedade internacional de biometria, 45, 255-258.

Fialho, M. B., Moraes, M. H. D., Tremocoldi, A. R., \& Pascholati, S. F. (2011). Potential of antimicrobial volatile organic compounds to control Sclerotinia sclerotiorum in bean seeds. Pesquisa Agropecuária Brasileira, 46(2), 137-142. http://dx.doi.org/10.1590/S0100-204X2011000200004

Hammami, I., Rhouma, A., Jaouadi, B., Rebai, A., \& Nesme, X. (2009). Optimization and biochemical characterization of a bacteriocin from a newly isolated Bacillus subtilis strain 14B for biocontrol of Agrobacterium spp. strains. Letters in applied microbiology, 48(2), 253-260.

Han, J. S., Cheng, J. H., Yoonm, T. M., Song, J., Rajkarnikar, A., Kim, W. G., ... Suh, J. W. (2005). Biological control agent of common scab disease by antagonistic strain Bacillus sp. sunhua. Journal of Applied Microbiology, 99, 213-221.

Hou, X., Boyetchko, S. M., Brkic, M., Olson, D., Ross, A., \& Hegedus, D. (2006). Characterization of the antifungal activity of a Bacillus spp. associated with sclerotia from Sclerotinia sclerotiorum. Applied Microbiology and Biotechnology, 72, 644-653.

Huang, H. C., Bremer, E., Hynes, R. K., \& Erickson, R. S. (2000). Foliar application of fungal biocontrol agents for the control of white mold of dry bean caused by Sclerotinia sclerotiorum. Biological Control, 18(3), 270-276. http://dx.doi.org/10.1006/bcon.2000.0829

Kado, C. I., \& Heskett, M. G. (1970). Selective media for isolation of Agrobacterium, Corynebacterium, Erwinia, Pseudomonas and Xanthomonas. Phytopathology, 60(6), 969-979. http://dx.doi.org/10.1094/Phyto-60-969

Kai, M., Effmert, U., Berg, G., \& Piechulla, B. (2007). Volatiles of bacterial antagonists inhibit mycelial growth of the plant pathogen Rhizoctonia solani. Archives of Microbiology, 187, 351-360. http://dx.doi.org/10.1007/s00203-006-0199-0 
Kennedy, A. C. (1999) Bacterial diversity in agroecosystems. Agriculture, Ecosystems \& Environment, 74(1-3), 65-76. http://dx.doi.org/10.1016/S0167-8809(99)00030-4

Kliebenstein, D. J. (2004). Secondary metabolites and plant/environment interactions: a view through Arabidopsis thaliana tinged glasses. Plant, Cell \& Environment, 27(6), 675-684. http://dx.doi.org/10.1111/j.1365-3040.2004.01180.x

Kloepper, J. W., Lifshitz, R., \& Zablotowicz, R. M. (1989). Free living bacterial inocula for enhancing crop productivity. Trends in Biochemical Science, 7, 39-44. http://dx.doi.org/10.1016/0167-7799(89)90057-7

Konings, W. N., Poolman, B., \& Driessen, A. M. (1992). Can the excretion of metabolites by bactéria be manipulated? FEMS Microbiology Letters, 88(2), 93-108. http://dx.doi.org/10.1016/0378-1097(92)90686-I

Kupper, K. C. (2003). Gimenes-Fernandes, N., Goes, A. de. Controle biológico de Colletotrichum acutatum, agente causal da queda prematura dos frutos cítricos. Fitopatologia Brasileira, 28, 251-257. http://dx.doi.org/10.1590/S0100-41582003000300005

Kutchan, T. M. (2001). Ecological arsenal and developmental dispatcher. The Paradigm of Secondary Metabolism. Plant Physiology, 58(125), 58-60. http://dx.doi.org/10.1104/pp.125.1.58

Leelasuphakul, W., Hemmanee, P., \& Chuenchitt, S. (2008). Growth inhibitory properties of Bacillus subtilis strains and their metabolites against the green mold pathogen (Penicillium digitatum Sacc.) of citrus fruit. Postharvest Biology and Technology, 48, 113-121. http://dx.doi.org/10.1016/j.postharvbio.2007.09.024

Marroni, I. V., \& Germani, J. C. (2011). Eficiência de rizobactérias Bacillus spp. no controle in vitro de Macrophomina phaseolina agente etiológico da podridão de tronco da mamona (Ricinus communis L). Revista Brasileira de Agroecologia, 6(3), 159-167.

Mccall, A. C., \& Karban, R. (2006). Induced defense in Nicotiana attenuata (Solanaceae) fruit and flowers. Oecologia, 146, 566-57. http://dx.doi.org/10.1007/s00442-005-0284-0

Mueller, D. S., Hartman, G. L., \& Pedersen, W. L. (1999). Development of sclerotia and apothecia of Sclerotinia sclerotiorum from infected soybean seed and its control by fungicide seed treatment. Plant Disease, 83(12), 1113-1115. http://dx.doi.org/10.1094/PDIS.1999.83.12.1113

Nagórska, K., Bikowski, M., \& Obuchowski, M. (2007). Multicellular behavior and production of a wide variety of toxic substances support usage of Bacillus subtilis as a powerful biocontrol agent. Acta Biochimica Polonica, 54(3), 495-508.

Ongena, M., Jourdan, E., Adam, A., Paquot, M., Brans, A., Joris, B., ... Thonart, P. (2007). Surfactin and fengycin lipopeptides of Bacillus subtilis as elicitors of induced systemic resistance in plants. Environmental Microbiology, 9(4), 1084-1090. http://dx.doi.org/10.1111/j.1462-2920.2006.01202.x

Paula Júnior, T. J., Vieira, R. F., \& Zambolim, L. (2004). Manejo integrado de doenças do feijoeiro em plantio direto. In L. Zambolim, A. A. Silva, \& E. L. Agnes (Eds.), Integração agricultura-pecuária (pp. 11-44). Viçosa, MG: UFV, 2004.

Remuska, A. C., \& Pria, M. D. (2007). Efeito de Bacillus thuringiensis e Trichoderma sp. no crescimento de fungos fitopatogênicos. Publicatio UEPG: Ciências Exatas e da Terra, Ciências Agrárias e Engenharias, 13(3), 31-36.

Ryu, C. M., Farag, M. A., Hu, C. H., Reddy, M. S., Kloepper, J. W., \& Paré, P. W. (2004). Bacterial volatiles induce systemic resistance in Arabidopsis. Plant Physiology, 134(3), 1017-1026. http://dx.doi.org/10.1104/pp.103.026583

Santos, E. R., Gouveia, E. R., Mariano, R. L. R., \& Souto-Maior, A. M. (2006). Controle biológico da mancha aquosa do melão por compostos bioativos produzidos por Bacillus spp. Summa Phytopathologica, 32(4), 376-378. http://dx.doi.org/10.1590/S0100-54052006000400010

Santos, R. I. (1999). Metabolismo Básico e origem dos metabólitos secundários. In: C. M. O. Simões, E. P. Schenkel, G. Gosmann (Eds.) (pp. 333-364), Farmacognosia: da planta ao medicamento. Porto Alegre/Florianópolis: Editora da UFRGS/Editora da UFSC.

Sossai, B. F., Rampazzo, C. S., Seawright, C. E., Rocha, E. W., Viudes, E. B., Vechiatto, F. A., ... Araujo, F. F. (2011). Efeito de tratamentos químicos e biológicos sobre o crescimento da alface. Colloquium Agrariae 7 (special), 1-188. 
Subbarao, K. V. (1998). Progress toward integrated management of lettuce drop. Plant Dis., 82, 1068-1078. http://dx.doi.org/10.1094/PDIS.1998.82.10.1068

Wang, J., Liu, J., Wang, X., Yao, J., \& Yu, Z. (2004). Application of electrospray ionization mass spectrometry in rapid typing of fengycin homologues produced by Bacillus subtilis. Letters in Applied Microbiology, 39(1), 98-102. http://dx.doi.org/10.1111/j.1472-765X.2004.01547.x

Wheatley, R. E. (2002). The consequences of volatile organic compound mediated bacterial and fungal interactions. Antonie van Leeuwenhoek, 81(1-4), 357-364.

Yang, D., Wang, B., Wang J., Chen, Y., \& Zhou, M. (2009). Activity and efficacy of Bacillus subtilis strain NJ-18 against rice sheath blight and Sclerotinia stem rot of rape. Biological Control, 51(1), 61-65. http://dx.doi.org/10.1016/j.biocontrol.2009.05.021

Yilmaz, M., Soran, H., \& Beyatli, Y. (2006). Antimicrobial activities of some Bacillus spp. strains isolated from the soil. Microbiological Research, 161(2), 127-131. http://dx.doi.org/10.1016/j.micres.2005.07.001

Yuen, G. Y., Godoy, G., Steadman, J. R., Kerr, E. D., \& Craig, M. L. (1991). Epiphytic colonization of dry edible bean by bacteria antagonistic to Sclerotinia sclerotiorum and potential for biological control of white mold disease. Biological Control, 1(4), 293-301. http://dx.doi.org/10.1016/1049-9644(91)90081-A

Zhang, C. X., Zhao, X., Jing, Y. X., Childa, T., Chen, H., \& Shen, S. H. (2008). Phenotypic and biological properties of two antagonist Bacillus subtilis strains. World Journal of Microbiology. Biotechnology, 24(10), 2179-2181. http://dx.doi.org/10.1007/s11274-008-9723-5

Zhang, J. X., \& Xue, A. G. (2010). Biocontrol of sclerotinia stem rot (Sclerotinia sclerotiorum) of soybean using novel Bacillus subtilis strain SB24 under control conditions. Plant Pathology, 59(2), 382-291. http://dx.doi.org/10.1111/j.1365-3059.2009.02227.x 